As the history gets closer to our time, it is difficult to agree with the presentation of different movements and individual poets, although I suppose we should be grateful that the poetry of Mandelshtam and Gumilev is discussed at all. The chapter on Symbolism (L. K. Dolgopolov) concentrates on the Symbolists' views of reality, social change, and revolution; their achievements in the sphere of poetic language and form are all but overlooked. The poetry of Zinaida Gippius is not discussed at all. Futurism fares far worse than Acmeism (both by V. V. Timofeeva); it is given only half the space accorded Acmeism (Mayakovsky's prerevolutionary poetry is allotted a separate chapter); some basic information about Futurism is not provided -thus, for example, we never learn who the members of "Tsentrifuga" were. Futurism's positive and lasting impact on the poetry of the twentieth century is only hinted at.

The monographic chapters on Pushkin (B. P. Gorodetsky), Lermontov (K. N. Grigorian), and Nekrasov (F. Ia. Priima) are among the least successful. All three are descriptive rather than analytical. Nekrasov the poet is drowned in the accounts of his ideological and civic virtues and in the retelling of many of his longer poems. Exceptionally fine is the chapter on the poetry of 1800-1810 (Iu. M. Lotman). Among the more successful monographic chapters is the one on Zhukovsky (N. V. Izmailov), which is perhaps the best in the work, and the ones on Tiutchev (N. V. Koroleva) and Baratynsky (I. M. Toibin).

It is characteristic, however, that the tragic sense of Baratynsky's late poetry is attributed mostly to the "reactionary reality of the post-Decembrist years" (1:356). Are we to believe that if the policies of Nicholas I had been more liberal, the poet would have turned into an optimist at peace with his time? Belinsky's devastating article on Sumerki is referred to simply as "izvestnaia stat'ia" (1:358, $367)$; the reader is enjoined to believe that the critic's disagreement with the poet was confined to questions of the philosophy of history.

The general impression of the work is rather contradictory. It can be useful, provided the reader does not take every statement on faith.

Olga Raevsky-Hughes

University of California, Berkeley

\title{
LITERATURE AND NATIONAL IDENTITY: NINETEENTH-CENTURY RUSSIAN CRITICAL ESSAYS. Translated and edited by Paul Debreczeny and Jesse Zeldin. Lincoln: University of Nebraska Press, 1970. xxv, 188 pp. $\$ 8.50$.
}

This volume contains five essays and an introductory article by Paul Debreczeny. The essays, all translated into English for the first time, are by Ivan Kireevsky (on Pushkin's poetry), Stepan Shevyrev (on Gogol's Dead Souls), Apollon Grigoriev (on Turgenev's $A$ Nest of the Gentry), Nikolai Strakhov (on War and Peace), and Vladimir Soloviev (on Dostoevsky).

The Russian authors represented in this anthology are linked to one another by their espousal of religious values and, with the exception of Soloviev, their identification with Russian national traditions and attitudes. As such, they contrast with the Westerner and radical literary critics-the school of Belinsky, Chernyshevsky, Dobroliubov, Pisarev, et al. Despite this divergence in world view, in the essays included in this book one does not directly encounter polemics with the writings of Westerner critics. In fact, in common with the Belinsky school, these five authors, to 
a greater or lesser degree, emphasize that the basic and ultimate purposes of literature are extra-aesthetic. The boldest statements to this effect are by Grigoriev and Soloviev respectively: "But for me an artistic work is a revelation of the great secrets of the soul and of life, the sole decider of social and ethical questions" (p. 108); "Artists and poets must again become priests and prophets, ... not only will the religious idea possess them, but they will possess it and consciously govern its earthly incarnations" (p. 171). The importance attributed to art, by conservatives and radicals alike, reflects the absence of democratic political life in nineteenth-century Russia. Then, as now, literature and its study served both as a compensation for such absence and as an alternative vehicle for the propagation of ideologies.

The translators are to be commended for producing generally readable and what appear to be accurate versions. The texts are annotated, and a helpful index is included.

\section{Arthur Levin \\ University of Calgary}

\section{APOLLON GRIGOR'EV: SOCHINENIIA. Vol. 1: KRITIKA. Edited, with an introductory essay and notes, by $V . S$. Krupitsch. Villanova: Villanova Univer- sity Press, 1970. xxxvi, 415 pp.}

This edition of some of Apollon Grigoriev's more important articles and reviews is a most meritorious undertaking, especially since Professor Krupitsch has taken care not to include in his collection any of the material printed in the Gosizdat edition of 1967. His selection is a representative one, and perfectly adequate for the purpose of acquainting a student of Russian literature with Grigoriev's thought. It will no doubt appear on many reading lists from now on.

Professor Krupitsch has provided his selection with ample and useful explanatory notes, which are, however, marred by some minor inaccuracies and misprints. His introductory essay shows his deep interest and justified admiration for Grigoriev —an important, immensely likable, and long-neglected figure. Understandably, Professor Krupitsch is overly enthusiastic on occasion. Thus when pointing out, quite correctly, that Grigoriev had considerable influence on Dostoevsky, he goes on to say: "It is now known that Grigor'ev's philosophical thought was profounder and more original than Dostoevsky's, and that the latter's fame was earned partly by his expression of the former's thought" (p. xxxiii). Since Professor Krupitsch does not prove this thesis, or quote his authority for it, it leaves the reader merely wondering. Unfortunately Professor Krupitsch has chosen to write his introduction in English, and his editors have done an unbelievably careless job of proofreading. As a result, the whole text makes for rather painful reading.

\section{VICTOR TERRAS Brown University}

THE SUBCONSCIOUS IN GOGOL' AND DOSTOEVSKIJ, AND ITS ANTECEDENTS. By Leonard J. Kent. Slavistic Printings and Reprintings, 75. The Hague and Paris: Mouton, 1969. 172 pp. 30 Dutch guilders.

It is now becoming almost as fashionable and interesting for American critics to seek an understanding of literature outside the literary text itself as it was mandatory 